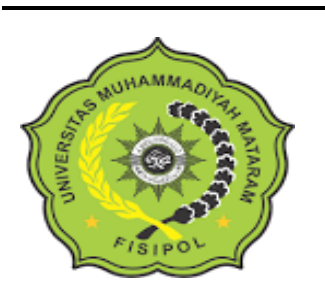

Journal of Government and Politics (JGOP) ISSN:2686-3391

Vol. 2 No. 2 Desember 2020

\title{
Journal of Government and Politics (JGOP)
}

http://journal.ummat.ac.id/index.php/jsip

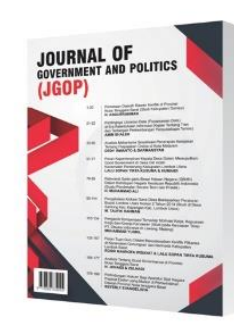

\section{$\overline{\text { Peran Pemerintah Dalam Pengawasan Hak Tenaga Kerja Wanita Pada }}$ Perusahaan Di Kabupaten Bungo Provinsi jambi}

\author{
Mela Sari ${ }^{1}$, M. Awaluddin ${ }^{2}$, \\ ${ }^{1}$ Sekolah Tinggi Ilmu Administrasi Setih Setio \\ ${ }^{2}$ Politeknik Negeri Pontianak
}

InfoArtikel

Sejarah Artikel:

Diterima: 14-10-2020

Disetujui: 17-12-2020

Dipublikasikan : 22-

12-2020

Kata Kunci :

Government;

Supervision; Woman

Workers
Pengawasan ketenagakerjaan merupakan unsur penting dalam perlindungan tenaga kerja, sekaligus upaya penegakan hukum ketenagakerjaan serta untuk menjamin terlaksananya peraturan perundang-undangan ketenagakerjaan tersebut. Tujuan penelitian ini adalah untuk mengetahui peran pemerintah dalam pengawasan hakhak tenaga kerja wanita pada perusahaan, serta untuk mendeskripsikan faktor pendukung serta penghambat dalam pengawasan hak hak tenaga kerja wanita pada perusahaan di kabupaten Bungo. Metode yang digunakan dalam penelitian ini adalah metode deskriptif dengan pendekatan kualitatif, dengan jumlah informan 16 orang diantaranya Koordinator wilayah IV Pengawasan Ketenagakerjaan Kabupaten Bungo-Tebo, Penyidik pegawai negeri sipil, 3 orang pengawas ketenagakerjaan koordinator wilayah IV Kabupaten Bungo-Tebo, dan 11 orang wanita yang bekerja pada perusahaan di Kabupaten Bungo. Hasil penelitian menunjukkan pemerintah telah berperan agar terpenuhinya hak-hak tenaga kerja wanita berdasarkan peraturan perundang-undangan melalui beberapa tahap pengawasan yaitu Preventive Control, Repressive Control, pengawasan saat proses dilakukan, pengawasan berkala, pengawasan mendadak, dan pengawasan melekat. Faktor pendukung dalam pengawasan yaitu regulasi, metode dan kapasitas, sedangkan faktor yang menghambat yaitu fasilitas dan koordinasi. 


\title{
THE ROLE OF GOVERNMENT ON WOMEN WORKERS RIGHT IN BUNGO REGENCY JAMBI PROVINCE
}

\begin{abstract}
Labor supervision is an important aspect on labor protection, as efforts to enforce the labor law and to ensure its implementation. The purpose of this study was to determine the role of the government in monitoring the rights of women workers, and to describe the supporting and inhibiting factors in supervising the rights of women workers in Bungo regency. The method of this study used a descriptive technique by a qualitative approach, with 16 informants in Coordinator Region IV of Bungo-Tebo Labor supervision, a civil servant investigator, 3 labor supervisors of coordinator Region IV Bungo-Tebo Regency, and 11 women who works for a company in Bungo Regency. The results show that the government has played a role in carrying the rights of women workers out by the regulations through several stages of supervision, namely Preventive Control, Repressive Control, supervision during the process, periodic supervision, sudden supervision, and inherent supervision. Supporting factors in supervision are regulations, methods and capacities, while inhibiting factors are facilities and coordination.
\end{abstract}

*Alamat Korespondensi:

${ }^{1}$ Melazuhel@gmail.com

${ }_{3}^{2}$ Awaldompu@gmail.com 


\section{PENDAHULUAN}

Dengan semakin meningkatnya perkembangan industrialisasi dan teknologi semakin canggih membawa wanita pada posisi yang sejajar dengan laki-laki karena teknologi yang serba otomatis dan praktis, tidak ada lagi hambatan bagi wanita untuk melakukan pekerjaan di berbagai bidang. Pembangunan ketenagakerjaan sebagai bagian integral dari pembangunan nasional berdasarkan Pancasila dan Undang-Undang Dasar Negara Republik Indonesia Tahun 1945, dilaksanakan dalam rangka pembangunan manusia Indonesia seutuhnya dan pembangunan masyarakat Indonesia seluruhnya untuk meningkatkan harkat, martabat, dan harga diri tenaga kerja serta mewujudkan masyarakat sejahtera, adil, makmur dan merata, baik materiil maupun spiritual.

Di Indonesia, adapun peraturan yang berkaitan dengan pembangunan ketenagakerjaan sudah diatur dalam Undang-Undang Nomor 13 Tahun 2003 tentang Ketenagakerjaan. Seorang pekerja tidak hanya orang yang mampu melakukan pekerjaan guna menghasilkan barang dan jasa yang kemudian mendapatkan upah atau imbalan. Terdapat hak-hak yang wajib diberikan kepada pekerja yang terkadang belum diketahui oleh pengusaha atau pemberi kerja, terutama hak-hak atau perlindungan kepada pekerja wanita / perempuan. Tidak hanya di Indonesia, khususnya Kabupaten Bungo juga terdapat perusahaan-perusahaan yang melakukan pelanggaran terhadap tenaga kerja wanita yang menyimpang dari peraturan perundang-undangan mengenai ketenagakerjaan. Mengingat wanita kini sudah mampu untuk melakukan pekerjaan di berbagai bidang, sebagaimana terlihat dari table 1 di bawah ini.

\section{Tabel 1}

Jumlah Tenaga Kerja Wanita di Kabupaten Bungo Berdasarkan Sektor atau Bidang Tahun 2019

\begin{tabular}{|l|l|l|}
\hline NO & SEKTOR / BIDANG & $\begin{array}{l}\text { TENAGA KERJA } \\
\text { WANITA }\end{array}$ \\
\hline $\mathbf{1}$ & Pertanian & 21.769 \\
\hline $\mathbf{2}$ & Manufaktur & 4.097 \\
\hline $\mathbf{3}$ & Jasa & 29.861 \\
\hline \multicolumn{2}{|l|}{ Jumlah } & $\mathbf{5 5 . 7 2 7}$ \\
\hline
\end{tabular}

Sumber : Badan Pusat Statistik Kabupaten Bungo, Bungo Dalam Angka, 2019 
Journal of Government and Politics (JGOP) Vol. 2 No. 2 Desember 2020 Hal. 181-191

Berdasarkan tabel di atas, jumlah tenaga kerja wanita di berbagai bidang yang ada di Kabupaten Bungo pada tahun 2019 sebanyak 55.727 orang. Undang-undang telah memberikan perlindungan terhadap hak-hak dasar pekerja. Pengusaha atau siapa pun yang melanggar hak-hak dasar pekerja dapat dijatuhkan sanksi mulai dari sanksi ringan seperti teguran, peringatan, pencabutan usaha sampai pada tingkat pelanggaran yang dapat digolongkan sebagai kejahatan sehingga dapat dikenakan sanksi kurungan atau pidana penjara. Berdasarkan Undang-Undang Nomor 13 tahun 2003 tentang Ketenagakerjaan, Hak-hak dasar pekerja antara lain menyangkut : perlindungan upah, jam kerja, tunjangan, kompensasi PHK, dan hak istirahat / cuti. Namun, berkaitan dengan hak-hak tenaga kerja wanita adapun masalah atau fenomena yang terjadi di Kabupaten Bungo, yakni : Masih banyak tenaga kerja wanita tidak mengetahui tentang peraturan perundang-undangan mengenai Ketenagakerjaan terkait hak-hak yang seharusnya mereka peroleh dalam bekerja dan hanya berpedoman pada peraturan perusahaan saja; Ada beberapa pasal pada UndangUndang Nomor 13 Tahun 2003 tentang Ketenagakerjaan menyangkut hak-hak pekerja wanita, seperti hak cuti haid, cuti melahirkan, hak menyusui anak atau penyediaan ruang laktasi dan jaminan sosial tenaga kerja / BPJS Kesehatan maupun BPJS Ketenagakerjaan yang belum diterapkan dengan baik oleh perusahaan; Ada tenaga kerja wanita yang dipekerjakan di luar jam kerja atau lembur hingga mala untuk pembukuan akhir bulan dan akhir tahun tetapi tidak diberikan makanan dan minuman yang bergizi hanya diganti dengan uang. Berkaitan dengan hal itu, pada kesempatan ini peneliti akan menganalisis secara mendalam dan lebih lanjut bagaimana pengawasan dari pemerintah terhadap tenaga kerja wanita agar hak-hak mereka dapat terpenuhi dengan sebaik-baiknya dan menjamin pelaksanaan peraturan perundang-undangan ketenagakerjaan.

\section{METODE PENELITIAN}

Metode Penelitian kualitatif dan jenis deskriptif yaitu bermaksud untuk mengetahui serta mendapatkan gambaran tentang permasalahan yang terjadi di lapangan dalam waktu tertentu, kemudian berusaha menganalisa dan menjelaskan fenomena-fenomena yang terjadi untuk pemecahan masalah mengenai fakta-fakta dan sifat-sifat populasi. Fokus penelitian dalam penelitian ini adalah menganalisis peran pemerintah dalam pengawasan hak-hak ketenagakerjaan wanita pada perusahaan di Kabupaten Bungo serta mengidentifikasi dan menganalisis faktor pendukung dan penghambat peran pemerintah dalam pengawasan hak-hak ketenagakerjaan wanita pada perusahaan di Kabupaten Bungo. Penelitian ini mengambil situs penelitian di Kantor Pengawasan Ketenagakerjaan 
Journal of Government and Politics (JGOP) Vol. 2 No. 2 Desember 2020 Hal. 181-191

Koordinator Wilayah IV Kabupaten Bungo-Tebo dan perusahaan yang ada di Kabupaten Bungo. Dalam penelitian ini, sebagai instrumen penelitiannya adalah peneliti sendiri dengan menggunakan alat bantu penelitian berupa : alat tulis, pedoman wawancara, kamera dan voice recorder.

Pemilihan informan dalam penelitian ini menggunakan teknik purposive yakni teknik penentuan informan dengan pertimbangan tertentu. Maka, informan yang akan dimintai keterangan untuk penelitian di lapangan ialah : Koordinator wilayah IV Pengawasan Ketenagakerjaan Kabupaten Bungo-Tebo, Penyidik Pegawai Negeri Sipil (PPNS) pengawasan ketenagakerjaan koordinator wilayah IV Kabupaten Bungo-Tebo, pegawai pengawasan ketenagakerjaan koordinator wilayah IV Kabupaten Bungo-Tebo, dan tenaga kerja wanita yang bekerja pada perusahaan di Kabupaten Bungo.

Jenis data yang terdapat dalam penelitian ini adalah data primer dan data sekunder yang diambil meliputi kata-kata dan tindakan, sumber tertulis dan foto. Teknik pengumpulan data yang digunakan adalah wawancara, dokumentasi, observasi dan studi pustaka. Data yang diperoleh dari informan selanjutnya akan dianalisis secara sistematis dengan melakukan tiga langkah secara bersamaan yaitu kondensasi data, penyajian data, penarikan kesimpulan dan verifikasi.

\section{HASIL DAN PEMBAHASAN}

\section{Peran Pemerintah dalam Pengawasan Hak-Hak Ketenagakerjaan Wanita pada Perusahaan di Kabupaten Bungo}

Pengawasan pada dasarnya dilakukan untuk menghindari terjadinya penyimpangan dan penyelewengan atas tujuan yang akan dicapai. Pengawasan ketenagakerjaan merupakan unsur penting dalam perlindungan tenaga kerja, sekaligus upaya penegakan hukum ketenagakerjaan. Disamping sebagai upaya perlindungan tenaga kerja, pengawasan ketenagakerjaan juga memiliki tujuan sosial dalam melindungi wanita. Peran pemerintah pada dasarnya dalam melaksanakan tugas pengawasan, khususnya tenaga kerja wanita yaitu berdasarkan Standar Operasional Prosedur mengenai pengawasan dan pembinaan norma perlindungan tenaga kerja wanita. Berdasarkan hasil penelitian rika lestari (2016) terkait perlindungan hukum terhadap hak tenaga kerja wanita menyatakan bahwa Perlindungan Hukum Terhadap Hak Tenaga Kerja Wanita di PT. Beka Engineering Pangkalan Kerinci belum terpenuhi secara maksimal. Hal ini dapat terlihat dari tidak terpenuhi sebagian hak pekerja/buruh perempuan. Perlindungan hukum terhadap pekerja/buruh perempuan yang berkerja hingga malam hari diantaranya tidak terpenuhinya hak untuk mendapatkan 
Journal of Government and Politics (JGOP) Vol. 2 No. 2 Desember 2020 Hal. 181-191

angkutan antar jemput, kurangnya kamar mandi/wc yang disediakan, pemenuhan hak pekerja/buruh mendapatkan makanan dan minuman yang bergizi belum terpenuhi, perlindungan terhadap pemberian hak cuti hamil / melahirkan yang hanya diberikan selama 1 (satu) bulan sebelum saatnya melahirkan anak dan 1 (satu) bulan sesudah melahirkan, perlindungan terhadap hak cuti haid yang ketika merasakan sakit pada masa haid hanya diberikan waktu istirahat di ruangan yang telah disediakan dan tidak diberikan cuti, dan perlindungan terhadap upah yang diberikan kepada pekerja/buruh perempuan yang mengajukan hak cuti hamil / melahirkan yang hanya diberikan kepada pekerja/buruh perempuan yang mengajukan cuti hamil / melahirkan 1 (satu) bulan gaji.

Adapun kewenangan dalam pengawasan ketenagakerjaan ini adalah tugas dari kantor Pengawasan Ketenagakerjaan Koordinator Wilayah IV Kabupaten Bungo-Tebo. Dalam melaksanakan tugas pokok dan fungsinya dalam pengawasan maka pemerintah melakukan beberapa tahap, yaitu :

\section{1) Preventive Control}

Preventive control adalah pengawasan yang dilakukan sebelum kegiatan dilakukan untuk menghindari terjadinya penyimpangan-penyimpangan dalam pelaksanaannya. Berdasarkan hasil penelitian, pada pelaksanaannya pemerintah telah mengadakan sosialisasi dengan melibatkan perwakilan dari perusahaan dan beberapa tenaga kerja wanita pada perusahaan yang bersangkutan. Sosialisasi tersebut salah satunya membahas tentang hakhak yang diperoleh tenaga kerja wanita dari perusahaan sesuai dengan peraturan perundangundangan mengenai ketenagakerjaan tetapi sosialisasi tersebut masih dinilai kurang efektif karena tidak melibatkan seluruh tenaga kerja wanita yang ada di Kabupaten Bungo sehingga masih adanya tenaga kerja wanita yang tidak mengetahui peraturan perundang-undangan mengenai ketenagakerjaan yang menjamin hak-hak mereka.

\section{2) Repressive Control}

Repressive control adalah pengawasan yang dilakukan setelah terjadi kesalahan dalam pelaksanaannya, dengan maksud agar tidak terjadi pengulangan kesalahan, sehingga hasilnya sesuai dengan yang diinginkan. Berdasarkan hasil penelitian, dalam pelaksanaannya pada saat pemerintah melakukan kunjungan ke perusahaan ternyata terdapat pelanggaran yang terjadi maka perusahaan tersebut diberikan teguran lisan terlebih dahulu, jika ternyata pada kunjungan selanjutnya masih belum diperbaiki maka akan dikeluarkan teguran tertulis berupa surat peringatan yang disebut dengan nota pemeriksaan kepada perusahaan yang bersangkutan. 
3) Pengawasan selanjutnya yaitu pengawasan saat proses dilakukan

Jika terjadi kesalahan segera diperbaiki. Berdasarkan hasil penelitian, dalam pelaksanaannya pemerintah akan memberikan surat peringatan berupa nota pemeriksaan hingga 2 kali dengan jeda waktu yang berbeda-beda tergantung pelanggaran yang dilakukan oleh perusahaan. Nota pemeriksaan ini berisikan pelanggaran-pelanggaran yang dilakukan oleh perusahaan agar segera diperbaiki. Nota pemeriksaan yang pertama diberi waktu lebih panjang dibandingkan nota pemeriksaan yang kedua. Tetapi jika pelanggaran telah diperbaiki setelah diberikan nota pemeriksaan yang pertama maka nota pemeriksaan yang kedua tidak akan dikeluarkan.

4) Pengawasan Berkala

Pengawasan berkala adalah pengawasan yang dilakukan secara berkala, misalnya per tahun, per bulan, per minggu dan lain-lain. Berdasarkan hasil penelitian, pengawasan ketenagakerjaan dilakukan minimal 1 tahun sekali untuk satu perusahaan tetapi bisa saja lebih jika terdapat pelanggaran. Yang mana dalam 1 bulannya pemerintah mengawasi 5 perusahaan sesuai dengan rencana kerja yang telah disusun. Dalam pelaksanaannya pengawasan yang dilakukan masih kurang maksimal karena tidak seimbangnya jumlah perusahaan yang ada di Kabupaten Bungo dengan pegawai Pengawasan Ketenagakerjaan Koordinator Wilayah IV Kabupaten Bungo-Tebo. Sehingga menyebabkan kurang maksimalnya pengawasan yang dilakukan pemerintah dan masih terdapatnya pelanggaranpelanggaran yang tidak diketahui atau terdeteksi oleh pemerintah.

\section{5) Pengawasan Mendadak (Sidak)}

Pengawasan mendadak adalah pengawasan yang dilakukan secara mendadak untuk mengetahui apa pelaksanaan atau peraturan-peraturan yang ada dilaksanakan atau tidak dilaksanakan dengan baik. Berdasarkan hasil penelitian, pengawasan mendadak ini akan dilakukan jika pemerintah mendapatkan laporan bahwa telah terjadi penyimpangan atau pelanggaran khususnya bagi tenaga kerja wanita pada suatu perusahaan. Pada pelaksanaanya, pemerintah jarang sekali mendapatkan laporan langsung dari masyarakat maupun tenaga kerja wanita itu sendiri yang mana salah satu alasannya yaitu takut kehilangan pekerjaan, sehingga tenaga kerja wanita terpaksa harus patuh pada ketentuanketentuan yang dibuat oleh pihak perusahaan.

6) Pengamatan Melekat (waskat)

Pengamatan melekat adalah pengawasan yang dilakukan secara integratif mulai dari sebelum, pada saat dan sesudah kegiatan dilakukan. Berdasarkan hasil penelitian, tahap- 
Journal of Government and Politics (JGOP) Vol. 2 No. 2 Desember 2020 Hal. 181-191

tahap atau siklus dalam pelaksanaan pengawasan dimulai dengan berkunjung sekaligus sosialisasi kepada perusahaan dan tenaga kerja wanita selanjutnya jika terdapat pelanggaran pada saat pengawasan maka pemerintah akan memberikan teguran lisan kemudian jika masih diabaikan dilanjutkan dengan teguran tertulis. Dalam teguran tertulis pemerintah mengeluarkan surat peringatan berupa nota pemeriksaan sebanyak maksimal 2 kali kemudian tahap selanjutnya yaitu penyelidikan, Berita Acara Pemeriksaan (BAP) dilakukan oleh Penyidik Pegawai Negeri Sipil Ketenagakerjaan bekerjasama dengan Polri. Setelah penyidikan selesai barulah dibawa ke Pengadilan.

Faktor Pendukung dan Penghambat dalam Pengawasan Hak-hak Ketenagakerjaan Wanita pada Perusahaan di Kabupaten Bungo

\section{Faktor Pendukung}

1) Regulasi

Menurut Adil Najam dalam jurnal "Implementasi Kebijakan, sari mela 2019) konten kebijakan dapat dilihat dari kejelasan isi, isi kebijakan mudah dipahami dan diimplementasi oleh implementor, isi kebijakan dapat menemukan penyebab, menanggapi, memberi solusi dan tentunya pada akhirnya mengatasi permasalahan yang timbul di tengah-tengah masyarakat, kebijakan yang dirancang dapat didesain dan fokus pada pemecahan masalah sehingga dapat memberikan perubahan ke arah yang lebih baik. Berdasarkan hasil wawancara, diketahui bahwa para pelaksana pengawasan dalam hal ini adalah pegawai Pengawasan Ketenagakerjaan Koordinator Wilayah IV Kabupaten Bungo-Tebo dapat memahami beberapa regulasi tentang ketenagakerjaan salah satunya yaitu Undang-Undang Nomor 13 Tahun 2003 tentang Ketenagakerjaan. Kebijakan ini juga dapat menjadi pedoman bagi pemerintah dalam pengawasan ketenagakerjaan serta mampu menjadi solusi dalam memecahkan permasalahan yang terjadi. Maka dapat disimpulkan bahwa Regulasi menjadi salah satu faktor pendukung pemerintah dalam melaksanakan perannya agar menjamin terpenuhinya hak-hak dari tenaga kerja wanita dan upaya penegakan hukum ketenagakerjaan.

2) Metode

Pemerintah dalam melaksanakan pengawasan menerapkan tiga metode atau tahapan dalam penegakan hukum, yang pertama yaitu metode preventive educative atau upaya pembinaan, yang artinya mendahulukan pembinaan kepada perusahaan atau masyarakat industrinya diberikan pemahaman mengenai informasi dan ketentuan-ketentuan dalam ketenagakerjaan. Metode yang kedua yaitu metode refresif nonyustisial adalah hasil 
Journal of Government and Politics (JGOP) Vol. 2 No. 2 Desember 2020 Hal. 181-191

pemeriksaan dari perusahaan dalam bentuk peringatan tertulis atau nota pemeriksaan, nota pemeriksaan berisikan tentang hal-hal yang dilanggar dan hal-hal yang harus dipenuhi oleh perusahaan tentang apa-apa saja yang telah dilanggar, berapa denda dan jangka waktu yang harus dipenuhi oleh perusahaan tersebut, yang ke tiga yaitu refresif yustisial berupa tuntutan ketika nota pemeriksaan tidak dipenuhi oleh perusahaan. Pelaksanaan dari tindakan yang ketiga ini melalui proses penyidikan, Berita Acara Pemeriksaan (BAP) dilakukan oleh Penyidik Pegawai Negeri Sipil Ketenagakerjaan bekerjasama dengan Polri. Setelah penyidikan selesai barulah di bawa ke Pengadilan. Maka dapat disimpulkan bahwa metode ini dapat menjadi faktor pendukung dalam pengawasan ketenagakerjaan wanita pada perusahaan.

3) Kapasitas

Kapasitas atau kemampuan pemerintah dalam melaksanakan pengawasan harus mampu membawa perubahan sesuai dengan yang diharapkan, sehingga orang-orang yang terlibat dalam pelaksanaan pengawasan adalah orang yang mempunyai kemampuan di bidangnya agar dapat memberi kontribusi positif untuk keberhasilan dalam pengawasan ketenagakerjaan khususnya pengawasan hak-hak tenaga kerja wanita pada perusahaan. Berdasarkan hasil dari beberapa wawancara dapat dinilai bahwa dalam menjawab setiap pertanyaan yang diajukan, pegawai Pengawasan Ketenagakerjaan Koordinator Wilayah IV Kabupaten Bungo-Tebo memang menguasai serta mempunyai kompetensi dan independen guna menjamin pelaksanaan peraturan perundang-undangan ketenagakerjaan.

\section{Faktor Penghambat}

\section{1) Fasilitas}

Fasilitas menjadi salah satu pendukung dalam pelaksanaan kebijakan. Berdasarkan hasil penelitian, diketahui bahwa fasilitas yang dimiliki pemerintah dalam pengawasan ketenagakerjaan wanita pada perusahaan di Kabupaten Bungo masih belum memadai, misalnya kendaraan untuk melakukan kunjungan dan pengawasan ke perusahaan serta sarana prasarana kantor yang sangat minim. Sehingga hal tersebut menjadi faktor penghambat dalam melaksanakan pengawasan ketenagakerjaan wanita pada perusahaan di Kabupaten Bungo.

2) Koordinasi

Koordinasi menurut Hani Handoko (2013: 193) adalah proses pengintegrasian tujuan-tujuan dan kegiatan-kegiatan pada satuan-satuan yang terpisah (departemen atau bidang-bidang fungsional) suatu organisasi untuk mencapai tujuan organisasi secara efisien. 
Journal of Government and Politics (JGOP) Vol. 2 No. 2 Desember 2020 Hal. 181-191

Berdasarkan hasil penelitian, diketahui bahwa beberapa pelanggaran terjadi karena kurangnya koordinasi antara pemerintah dengan pihak perusahaan. Pada saat pemerintah mengadakan sosialisasi hanya melibatkan pihak perusahaan dan beberapa tenaga kerja wanita saja tetapi pihak perusahaan tidak menyampaikan hasil sosialisasi tersebut kepada tenaga kerja wanita lainnya yang ada diperusahaan tersebut. Selain itu, beberapa pasal yang mengatur tentang hak-hak yang harus dipenuhi perusahaan kepada tenaga kerja wanita belum diterapkan dengan baik disebabkan beberapa alasan, salah satunya yaitu kurangnya anggaran perusahaan. Maka dapat disimpulkan bahwa ini menjadi faktor penghambat dalam pengawasan ketenagakerjaan wanita pada perusahaan di Kabupaten Bungo. Hasil penelitian dari Desia Rakhma Banjarani (2019) menyatakan juga bahwa Dalam hal perlindungan pada buruh wanita, Indonesia belum meratifikasi seluruh Konvensi ILO terkait perlindungan pada buruh wanita sebut saja Konvensi tentang Perlindungan Kehamilan dan Konvensi ILO tentang Pekerja dengan Tanggung Jawab Keluarga. Hal ini yang menyebabkan kurang maksimalnya perlindungan buruh wanita di Indonesia. Sehingga diharapkan agar pemerintah Indonesia dapat segera meratifikasi kedua konvensi tersebut. Dengan adanya kasus pelecehan seksual dan diskriminasi gender di pabrik garmen dan perusahaan teknologi, tentu kasus ini merujuk pada penegakan hukum perlindungan wanita.

\section{PENUTUP}

Peran pemerintah dalam pengawasan hak-hak ketenagakerjaan wanita pada perusahaan di Kabupaten Bungo sudah dilakukan dengan baik oleh pemerintah melalui beberapa tahap atau waktu pengawasan berikut, yaitu preventive control, repressive control, pengawasan saat proses dilakukan, pengawasan berkala, pengawasan mendadak (sidak) dan pengamatan melekat (waskat). Namun pada pelaksanaannya masih terdapat pelanggaranpelanggaran yang dilakukan oleh perusahaan. Selain itu, ada juga tahap pengawasan yang belum optimal pelaksanaannya seperti pengawasan berkala dan pengawasan mendadak (sidak).

Faktor pendukung pelaksanaan peran pemerintah dalam pengawasan hak-hak ketenagakerjaan wanita pada perusahaan, yaitu : (1) Regulasi, isi kebijakan (UndangUndang Nomor 13 Tahun 2003) dapat menjadi pedoman bagi pemerintah dalam pengawasan ketenagakerjaan serta mampu menjadi solusi dalam memecahkan permasalahan yang terjadi, (2) Metode, ada 3 metode tahapan dalam penegakan hukum yaitu metode preventive educative, refresif nonyustisial dan refresif yustisial, (3) Kapasitas, pengawas ketenagakerjaan yang mempunyai kemampuan, kompetensi dan independen juga 
Journal of Government and Politics (JGOP) Vol. 2 No. 2 Desember 2020 Hal. 181-191

menjadi faktor pendukung terlaksananya pengawasan ketenagakerjaan. Faktor yang mengambat dalam dalam pengawasan hak-hak ketenagakerjaan wanita pada perusahaan, yaitu : (1) Fasilitas, sarana prasarana kantor yang sangat minim menjadi faktor penghambat dalam menunjang pelaksanaan pengawasan ketenagakerjaan wanita pada perusahaan di Kabupaten Bungo, (2) Koordinasi, kurangnya koordinasi antara pemerintah dengan pihak perusahaan menyebabkan beberapa pelanggaran terjadi sehingga pengawasan menjadi kurang efektif.

Berdasarkan hasil penelitian maka peneliti memberikan beberapa saran, pertama agar Pemerintah lebih meningkatkan sosialisasi kepada perusahaan maupun tenaga kerja wanita mengenai hak-hak ketenagakerjaan wanita dengan melibatkan keseluruhan tenaga kerja wanita di Kabupaten Bungo. Dan kedua, agar Pemerintah dalam menjalankan perannya serta melaksanakan tugas-tugasnya sebagai pengawas ketenagakerjaan harus lebih meningkatkan pengawasan dan menindak tegas perusahaan yang tidak memenuhi ketentuan dalam menerapkan hak cuti dan hak-hak tenaga kerja wanita lainnya.

\section{DAFTAR PUSTAKA}

Basrowi dan Suwandi. (2008). Memahami Penelitian Kualitatif. Jakarta: Rineka Cipta

El-Muhtaj, Majda. (2007). Hak Asasi Manusia dalam Konstitusi Indonesia. Jakarta: Kencana

Handoko Hani. (2013). Manajemen. Yogyakarta: BPFE

Husni, Lalu. (2006). Pengantar Hukum Ketenagakerjaan Indonesia. Jakarta: Rajagrafindo Persada

Kencana Syafiie, Inu dan Welasari. (2015). Ilmu Administrasi. Yogyakarta: Pustaka Pelajar Miles, Huberman, Saldana. (2014). Qualitative Data Analysis a Methods Sourcebook. United States of Amerika: SAGE Publications, Inc

Moleong, Lexy J. (2012). Metodologi Penelitian Kualitatif. Bandung: Remaja Rosdakarya Sugiyono. (2013). Metode Penelitian Kuantitatif, Kualitatif dan R\&D. Bandung: Alfabeta Banjarani, Desia Rakhma dkk (2019) “Pelaksanaan Dan Perlindungan Akses Hak Pekerja Wanita Di Indonesia: Telaah Undang-Undang No 13 Tahun 2003 Tentang Ketenagakerjaan Atas Konvensi Ilo” Jurnal HAM kemenristekdikti

Clinton, Bill (2016) “Perlindungan Hukum Terhadap Hak Tenaga Kerja Wanita Di Pt. Beka Engineering Pangkalan Kerinci” Jurnal Fakultas Hukum Unri Sari, Mela (2019) “Implementasi Kebijakan Pencegahan Kebakaran Hutan dan Lahan” 